慶應義塾大学学術情報リポジトリ

Keio Associated Repository of Academic resouces

\begin{tabular}{|c|l|}
\hline Title & Technetium-99m chelates as tumor visualizing agents \\
\hline Sub Title & \\
\hline Author & $\begin{array}{l}\text { 松島, 美一(Matsushima, Yoshikazu) } \\
\text { 加留部, 善晴( Karube, Yoshiharu) }\end{array}$ \\
\hline Publisher & 共立薬科大学 \\
\hline Publication year & 1983 \\
\hline Jtitle & $\begin{array}{l}\text { 共立薬科大学研究年報 (The annual report of the Kyoritsu College of } \\
\text { Pharmacy). No.28 (1983. ),p.108-109 }\end{array}$ \\
\hline JaLC DOI & \\
\hline Abstract & \\
\hline Notes & 学会講演要旨 \\
\hline Genre & Technical Report \\
\hline URL & https://koara.lib.keio.ac.jp/xoonips/modules/xoonips/detail.php?koara_id=AN00062898-0000002 \\
& $8-0113$ \\
\hline
\end{tabular}

慶應義塾大学学術情報リポジトリ(KOARA)に掲載されているコンテンツの著作権は、それぞれの著作者、学会または出版社/発行者に帰属し、その権利は著作権法によって 保護されています。引用にあたっては、著作権法を遵守してご利用ください。

The copyrights of content available on the KeiO Associated Repository of Academic resources (KOARA) belong to the respective authors, academic societies, or publishers/issuers, and these rights are protected by the Japanese Copyright Act. When quoting the content, please follow the Japanese copyright act. 


\title{
金属キレーションによる分子修飾
}

\author{
松島美一 \\ [第27回日本薬学会関東支部総会（1983年 5 月，東京）特別講演]
}

\begin{abstract}
有機分子と金属イオンとのキレーションを研究し, それを薬学分野に応用しよらとする演者の 従来の研究は大別して次の 2 つ方向がある。1は有機分子の機能が金属キレーションにより変 らないよらな配慮の上で行なわれる研究である。つまり有機分子の金属ラベルである。最も発展 している応用面に bifunctional chelate と呼ばれる一群の放射性医薬品がある。2 は金属キレー ションにより有機分子の機能や反応性を制御しょうとする研究である。例として金属キレート触 媒ピリドキサール酵素モデルの研究がある。
\end{abstract}

\section{Technetium-99m Chelates as Tumor Visualizing Agents}

\author{
松島美一，加留部善晴*
}

[1st International Conference on Bioinorganic Chemistry, Florence, Italy, June, 1983 で癹表]

For scintigraphic visualization of tissues and organs, $\mathrm{Tc}-99 \mathrm{~m}$ is an ideal radionuclide for its optimal half life, physical properties and good quality scintigrams. There is at present time no outstanding Tc-99 $\mathrm{m}$ radiopharmaceuticals for the imaging of various malignant tumors. There is an urgent need for such agents.

Hoping to find good radiotracers for tumors, we prepared Tc-99 $\mathrm{m}$ complexes of substances which were expected to have affinity for tumor tissues such as amino acids, peptides, and porphyrins and studied the scintigraphic behaviors in experimental animals bearing spontaneous or transplanted tumors.

Recently Tc-99 m complex of ethylenediamine- $N, N$-diacetic acid (EDDA) was found to give satisfactory scintigrams of Ehrlich tumor in mice. Sequential scintigrams show that the image of the tumor was recognized in $1 \mathrm{hr}$ and visualized very clearly $2-5 \mathrm{hr}$ after the i. v. administration of Tc-99 $\mathrm{m}$ complex of EDDA. The radioactivity was not accumulated in any specific organ other than the tumor and excreted through kidneys. The Tc-99 $\mathrm{m}$ EDDA complex was also effective for scintigraphic visualization of other malignant tumors in mice bearing Sarcoma 180, golden hamsters bearing lymphoma, mice bearing fibrosarcoma induced by 3 -methylcholanthrene (MC), rats bearing $\mathrm{MC}$ induced fibrosarcoma that had been transplanted at the limb and had spontaneously metastasized to the lung, and mice bearing spontaneous mammary carcinoma.

A number of chelating ligands structurally related to EDDA were examined for $\mathrm{Tc}-99 \mathrm{~m}$ labeled radiotracers for tumors. Among the Tc-99 $\mathrm{m}$ complexes examined, 
those of ethylenediamine- $N, N$-diacetic acid, $N$-hydroxyethyliminodiacetic acid, and propylene-1,3-diamine- $N, N$-diacetic acid achieved clear visualization of Ehrlich tumors.

The scintigraphic visualization of human tumors was also successful. Studies on the mechanism of the concentration in the tumor tissues of the Tc-99 $\mathrm{m}$ complexes are in progress in our laboratories.

* 福岡大学薬学部

\title{
培養動物細胞における $\mathrm{Zn}$ の細胞膜透過
}

\author{
小林静子, 岡田貴子 \\ [日本生化学会（1982年10月）で発表】
}

〔目的〕最近，栄養学の立場から $\mathrm{Zn}$ 於よびCuなどの微量の重金属重要性が注目されている。 これら金属の代謝を知る目的で Zn の膜透過について検討した。

〔万法〕 3T3, SV $403 \mathrm{~T} 3$ 細胞 (Swiss Albino) をDulbeccou's MEM 培地で培養した後, Hepes buffer ( $\mathrm{pH} 7.4$ ) で 30 分間 preincubate し, $10 \mu \mathrm{M} \mathrm{Zn}{ }^{2+}\left({ }^{65} \mathrm{Zn} 0.5 \mu \mathrm{Ci} / \mathrm{ml}\right.$ を含む) を添 加，0，2，5，10，20 分間それぞれ incubate する。反応停止および洗淮は cold Hepes bufferを 5 回交換して行なった。取り込みは, 細胞タンパク $\mathrm{mg}$ 当りの Zn p・moleで表わした。

〔結果・考察〕 $\mathrm{Zn}$ の取り込み量は，添加後 5 分まで值線性を示したが，その後減少した。ま た, SV $403 \mathrm{~T} 3$ 細胞では 3T3 に比較して 30〜40\% 増加していた。すなわち, 細胞の腫湯化に伴 って Zn の膜輸送能が増加していた。デキサメサゾンを添加しても取り込みには大きな影響は見 い出せなかった。glucocorticoid ホルモンはZnの細胞内取り込みおよび蓄積には直接関与せず, むしろメタロチオネインのプライマリーインデュサーとして働き, 誘導されたチオネイン分子に よって $\mathrm{Zn}$ が細胞内に引き込まれる様に見える。また, サイトカラシン B は $3 \mathrm{~T} 3$ 細胞の $\mathrm{Zn}$ 膜透 過に影響し $50 \%$ 増加したが， transformed 細胞では変化がない。

\section{培䖭細胞内での $\mathrm{Zn}$-thionein の分解と分解物}

\author{
小林静子, 岡田貴子, 木村正已* \\ [日本薬学会 第 103 年会（1983年 4 月）で発表】
}

〔目的〕細胞内で Znによって誘導された Zn-thionein は, Zn が容易に thionein 分子から遊 離し, 細胞外一排出される。同時に thionein 分子自体も加水分解される（第 1 回金属の関与す る生体関連反応シンポで報告)。今回はチオネイン分解の経時的変化と分解後, 細胞外に排出さ れてくる分解物について報告する。

[方法】 Chang's Liver Cell Line を 10\% FBS を含む MEM 培地, $5 \% \mathrm{CO}_{2}, 37^{\circ}$ の条件下で 培着した。 $5 \mu \mathrm{g} / \mathrm{ml}$ の $\mathrm{Zn} と 0.1 \mu \mathrm{Ci} / \mathrm{ml}$ の ${ }^{35} \mathrm{~S}-$ Cystine を加えて 15 時間培養した後, 培地を 